\title{
molecules
}

ISSN 1420-3049

http://www.mdpi.org

Full Paper

\section{Microwave Assisted Synthesis of Molybdenum and Tungsten Tetracarbonyl Complexes with a Pyrazolylpyridine Ligand. Crystal structure of cis-[Mo(CO) ${ }_{4}$ \{ethyl[3-(2-pyridyl)-1- pyrazolyl]acetate\}]}

Ana C. Coelho ${ }^{1}$, Filipe A. Almeida Paz ${ }^{1}$, Jacek Klinowski ${ }^{2}$, Martyn Pillinger ${ }^{1}$ and Isabel S. Gonçalves ${ }^{1, *}$

${ }^{1}$ Department of Chemistry, CICECO, University of Aveiro, 3810-193 Aveiro, Portugal

2 Department of Chemistry, University of Cambridge, Lensfield Road, CB2 1EW, Cambridge, United Kingdom; E-mail: jk18@cam.ac.uk

* Author to whom correspondence should be addressed; E-mail: igoncalves@dq.ua.pt

Received: 17 November 2006; in revised form: 4 December 2006 / Accepted: 5 December 2006 / Published: 6 December 2006

Abstract: We report the one-step syntheses in good yields of the complexes cis$\left[\mathrm{M}(\mathrm{CO})_{4}(\mathrm{pzpy})\right]\{\mathrm{M}=\mathrm{Mo}, \mathrm{W}$; pzpy = ethyl[3-(2-pyridyl)-1-pyrazolyl]acetate $\}$ directly from the corresponding $\mathrm{M}(\mathrm{CO})_{6}$ starting materials by using microwave-assisted heating and reaction times of either $30 \mathrm{~s}(\mathrm{M}=\mathrm{Mo})$ or $15 \mathrm{~min}(\mathrm{M}=\mathrm{W})$. The structure of the molybdenum tetracarbonyl complex was determined by single crystal X-ray diffraction. The compound is monomeric and the molybdenum atom has a highly distorted octahedral geometry. The close packing of the individual cis-[Mo(CO) $\left.)_{4}(\mathrm{pzpy})\right]$ species is essentially driven by the need to fill the space effectively, closely mediated by weak $\mathrm{C}-\mathrm{H} \cdots \mathrm{O}$ and $\pi \cdots \pi$ interactions.

Keywords: Tetracarbonyl metal complexes, pyrazolylpyridine ligand, microwave synthesis, X-ray structure 


\section{Introduction}

Transition metal carbonyl compounds continue to be investigated for applications in various fields, particularly catalysis [1-4], non-linear optics [5-7] and medicine [8-10]. The complexes may be homoleptic, such as molybdenum hexacarbonyl $\left[\mathrm{Mo}(\mathrm{CO})_{6}\right]$, or may contain a combination of ligands, such as $\left[\operatorname{Re}(\mathrm{CO})_{3}\left(2,2^{\prime}\right.\right.$-bipyridine $\left.) \mathrm{Cl}\right]$. They have been investigated as anti-cancer agents [11], biological tracer agents [12,13] and carbon monoxide-releasing molecules [14]. Several catalytic applications are also known. For example, $\left[\mathrm{Mo}(\mathrm{CO})_{6}\right]$ is used as a precursor to a $\mathrm{Mo}^{\mathrm{VI}}$ catalyst in the commercial process for the epoxidation of propylene by tert-butyl hydroperoxide [15]. Tetracarbonyl metal complexes of the type cis- $\left[\mathrm{M}(\mathrm{CO})_{4}(\mathrm{~L})_{\mathrm{n}}\right](\mathrm{M}=\mathrm{Cr}$, Mo, W or Re), bearing monodentate or bidentate organic donor ligands $(\mathrm{L})$, are also potentially interesting as catalyst precursors [2]. These compounds are usually prepared directly from the parent homoleptic metal carbonyls (by thermal or photochemical activation) or by treating cis-[M(CO) $\left.)_{4}(\text { pip })_{2}\right]$ (pip = piperidine) with a refluxing solution of the ligand $\mathrm{L}$ in an organic solvent. Hogarth and co-workers showed that the important synthon, cis-[Mo(CO) $\left.)_{4}(\mathrm{pip})_{2}\right]$, could be prepared in $80-90 \%$ yield over 30-40 min by microwaveassisted reflux (in comparison with the $4 \mathrm{~h}$ required by conventional reflux) [16]. It was subsequently reported that the microwave-assisted synthesis (MAS) of various compounds of the type $\left[\mathrm{M}(\mathrm{CO})_{4}(\mathrm{~L})_{n}\right]$, using either an open reflux system or a sealed teflon-lined autoclave, results in a reduction in reaction times and an increase in yields over previously published syntheses $[17,18]$. The rate enhancement results from the coupling of solvents with high dielectric loss tangents with the microwave's irradiation, resulting in super-heating, thereby leading directly to reaction acceleration. Despite these promising results, the potential use of microwave-accelerated syntheses of organometallic compounds has hardly been explored, especially when compared with work in organic synthesis using this method [19]. In the present work, we report the MAS of tetracarbonyl complexes of molybdenum and tungsten with a pyrazolylpyridine ligand. The crystal structure of the Mo complex is described. We are particularly interested in the coordination chemistry of pyrazolylpyridine ligands because their complexes often possess excellent catalytic or photophysical properties [20,21].

\section{Results and Discussion}

The treatment of cis-[Mo(CO) 4 (pip) 2 ] with the ligand ethyl[3-(2-pyridyl)-1-pyrazolyl]acetate (pzpy) in toluene at $50{ }^{\circ} \mathrm{C}$ for $3 \mathrm{~h}$ was reported to give the complex cis-[Mo(CO) 4 (pzpy)] (1) in 80\% yield [22]. We found that the same compound could be obtained directly from $\mathrm{Mo}(\mathrm{CO})_{6}$ in $63 \%$ yield by microwave-assisted heating (using a power of $300 \mathrm{~W}$ ) of a mixture of the hexacarbonyl and pzpy in diglyme and toluene at $180{ }^{\circ} \mathrm{C}$ for $30 \mathrm{~s}$. The corresponding tungsten tetracarbonyl complex, cis[W(CO) 4 (pzpy)] (2), was obtained in $85 \%$ yield by MAS at $180{ }^{\circ} \mathrm{C}$ for $15 \mathrm{~min}$, using a power of 600 $\mathrm{W}$. A slightly longer reaction time was required for the formation of the tungsten complex due to the lower reactivity of $\mathrm{W}(\mathrm{CO})_{6}$ [23]. The IR spectra of $\mathbf{1}$ and $\mathbf{2}$ show four active $v(\mathrm{C} \equiv \mathrm{O})$ normal modes in the $1810-2015 \mathrm{~cm}^{-1}$ range, typical of cis-[M(CO) $\left.{ }_{4} \mathrm{~L}\right]$ molecules. A further band is observed at 1750 $\mathrm{cm}^{-1}$ for the CO group of the pzpy ligand. The complexes were also characterized by ${ }^{1} \mathrm{H}-$ and ${ }^{13} \mathrm{C}$ NMR spectroscopy (see Experimental section for details).

The structure of cis-[Mo(CO) 4 (pzpy)] (1) was confirmed by single crystal X-ray diffraction. A suitable crystal was obtained by slow diffusion of hexane into a solution of $\mathbf{1}$ in diethyl ether. Even 
though molybdenum complexes containing four or more carbonyl groups in the first coordination sphere are relatively common, as revealed by a search in the literature and in the Cambridge Crystallographic Database (CSD - Version 5.27, November 2005) [24,25], those containing organic ligands with $\mathrm{N}$-aromatic donor atoms are far less common. Most of the reported structures belonging to this family contain either 2-pyridyl substituted ligands [26-38], 2,2'-bipyridine [39-46] or 1,10phenanthroline [47,48] (and their derivatives). Thiel and co-workers described two structures for tetracarbonyl complexes of molybdenum chelated by 2-(3-pyrazolyl)pyridine residues [22,49]. To the best of our knowledge, no crystal structures have been reported for group 6 tetracarbonyl complexes containing the ethyl[3-(2-pyridyl)-1-pyrazolyl]acetate ligand.

Compound 1 crystallizes in the space group $P 2_{1} / c$ and the structure is composed of a single crystallographically unique molybdenum complex with the metallic centre being coordinated to four carbonyl groups and a bidentate N,N-chelating pzpy residue (Figure 1), giving a coordination geometry that resembles a highly distorted octahedron, $\left\{\mathrm{MoC}_{4} \mathrm{~N}_{2}\right\}$. The substantial deformation arises, in part, from the markedly distinct Mo-C and Mo-N bond distances [found in the 1.954(4)-2.050(4) and 2.248(3)-2.275(3) Å ranges, respectively - see Table 1]. These values lie within the known ranges for related compounds, as revealed by searches in the CSD: For Mo-C $\equiv \mathrm{O}$ (from 3194 entries), the bond length range is $1.48-2.37 \AA$ with a median of $1.98 \AA$; for Mo- $(\mathrm{N}, \mathrm{N})_{\text {chelate }}$ (from 529 entries), the bond length range is 1.92-2.64 $\AA$ with a median of $2.24 \AA$. A significant angular dispersion for the cis [71.63(9)-103.15(11) ${ }^{\circ}$ and trans [167.24(12)-170.12(14) ${ }^{\circ}$ ] octahedral angles is also registered. These distortions are in close agreement with those observed in related compounds as they essentially arise from the $\mathrm{N}, \mathrm{N}$-chelating nature of the pzpy residue. In fact, the most acute cis angle corresponds directly to the bite angle which is usually found in the range of $65.8-88.6^{\circ}$ (529 entries; median $74.7^{\circ}$ ). The bite angle for $\mathbf{1}$ is in perfect agreement with the average value of $71.6^{\circ}$ for the two structures reported by Thiel and co-workers [22,49].

Figure 1. Schematic representation of the complex cis-[Mo(CO) $\left.)_{4}(\mathrm{pzpy})\right]$ present in the crystal structure of $\mathbf{1}$, showing the labelling scheme for all non-hydrogen crystallographically independent atoms. Thermal ellipsoids have been drawn at the $30 \%$ probability level.

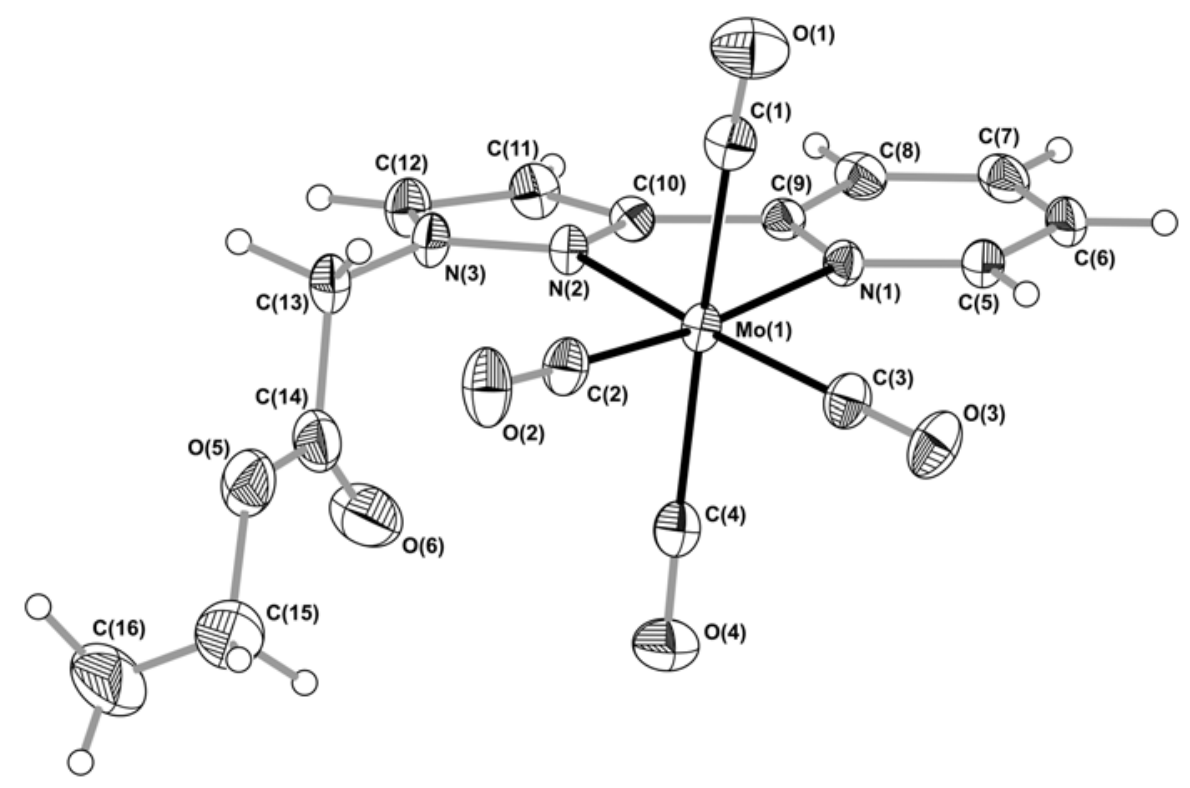


Table 1. Bond lengths $(\AA)$ and angles $\left(^{\circ}\right)$ for the octahedral $\left\{\mathrm{MoC}_{4} \mathrm{~N}_{2}\right\}$ coordination environment of the complex cis-[Mo(CO) $)_{4}$ (pzpy)].

\begin{tabular}{llll}
\hline $\mathrm{Mo}(1)-\mathrm{C}(1)$ & $2.039(4)$ & $\mathrm{Mo}(1)-\mathrm{C}(4)$ & $2.050(4)$ \\
$\mathrm{Mo}(1)-\mathrm{C}(2)$ & $1.957(4)$ & $\mathrm{Mo}(1)-\mathrm{N}(1)$ & $2.275(3)$ \\
$\mathrm{Mo}(1)-\mathrm{C}(3)$ & $1.954(4)$ & $\mathrm{Mo}(1)-\mathrm{N}(2)$ & $2.248(3)$ \\
& & & \\
$\mathrm{C}(1)-\mathrm{Mo}(1)-\mathrm{C}(4)$ & $170.12(14)$ & $\mathrm{C}(3)-\mathrm{Mo}(1)-\mathrm{C}(2)$ & $89.07(14)$ \\
$\mathrm{C}(1)-\mathrm{Mo}(1)-\mathrm{N}(1)$ & $91.93(12)$ & $\mathrm{C}(3)-\mathrm{Mo}(1)-\mathrm{C}(4)$ & $85.98(15)$ \\
$\mathrm{C}(1)-\mathrm{Mo}(1)-\mathrm{N}(2)$ & $98.17(12)$ & $\mathrm{C}(3)-\mathrm{Mo}(1)-\mathrm{N}(1)$ & $96.38(12)$ \\
$\mathrm{C}(2)-\mathrm{Mo}(1)-\mathrm{C}(1)$ & $85.40(15)$ & $\mathrm{C}(3)-\mathrm{Mo}(1)-\mathrm{N}(2)$ & $167.24(12)$ \\
$\mathrm{C}(2)-\mathrm{Mo}(1)-\mathrm{C}(4)$ & $88.30(15)$ & $\mathrm{C}(4)-\mathrm{Mo}(1)-\mathrm{N}(1)$ & $95.06(12)$ \\
$\mathrm{C}(2)-\mathrm{Mo}(1)-\mathrm{N}(1)$ & $173.78(12)$ & $\mathrm{C}(4)-\mathrm{Mo}(1)-\mathrm{N}(2)$ & $90.66(12)$ \\
$\mathrm{C}(2)-\mathrm{Mo}(1)-\mathrm{N}(2)$ & $103.15(11)$ & $\mathrm{N}(2)-\mathrm{Mo}(1)-\mathrm{N}(1)$ & $71.63(9)$ \\
$\mathrm{C}(3)-\mathrm{Mo}(1)-\mathrm{C}(1)$ & $86.32(14)$ & & \\
\hline
\end{tabular}

The Mo-C bond lengths for $\mathbf{1}$ (Table 1) fall into two groups, probably through distinct $\pi$ backbonding, $\mathrm{Mo}(d) \rightarrow \mathrm{C} \equiv \mathrm{O}\left(\pi^{*}\right)$. While the equatorial-coordinated carbonyl groups are competing with the less $\pi$-acidic $\mathrm{N}$-donor atoms from the pyrazolylpyridine ligand, the trans-coordinated groups compete with each other. Thus, the bond lengths for the latter [2.039(4) and 2.050(4) $\AA$ ] are about $0.09 \AA$ longer than those for the former [1.957(4) and 1.954(4) $\AA$ ].

The two N-donor atoms and the two carbonyl groups which make up the equatorial pseudo-plane of the $\left\{\mathrm{MoC}_{4} \mathrm{~N}_{2}\right\}$ octahedron are not all located on the same geometrical plane. Indeed, the carbonyl group containing $\mathrm{C}(3)$ is slightly above (by about $2.2^{\circ}$ ) the plane made by $\mathrm{N}(1)-\mathrm{N}(2)-\mathrm{C}(2)$. Even within the ligand pzpy, planarity is not maintained upon coordination to Mo and a dihedral angle of about $5.8^{\circ}$ is observed between the two rings. This distortion was also reported by Thiel and co-workers [22], but only for the compound with an ethyl acetate substituent at $\mathrm{N}(3)$ [this compound also had a ferrocenyl substituent on the pyrazole ring]. Consequently, it is reasonable to assume that the increased flexibility of this substituent leads to a significant steric hindrance during the close packing stage, which may be partially compensated by twisting the pyridine and the pyrazole rings out of co-planarity. The angle between the two coordinated carbonyl groups forming this equatorial plane, $\mathrm{C}(3)-\mathrm{Mo}(1)-\mathrm{C}(2)$, is close to ideal and this indicates that the weak $\mathrm{C}-\mathrm{H} \cdots \mathrm{O}$ hydrogen bonding interactions involving these groups (see below) have a radial geometry, thus not significantly compressing this section of the $\left\{\mathrm{MoC}_{4} \mathrm{~N}_{2}\right.$ \} octahedron.

The two mutually trans-coordinated carbonyl groups containing $\mathrm{C}(1)$ and $\mathrm{C}(4)$ are bent away from the chelating pyrazolylpyridine ligand to give a C(1)-Mo(1)-C(4) bond angle of $170.12(14)^{\circ}$ and the long Mo-C bonds mentioned above (Table 1). This crowding feature follows the trends reported for related complexes with, for example, the corresponding inter-moiety angle usually being found in the range of $160.7-174.5^{\circ}$ (from 52 entries in the CSD with a median of $169.2^{\circ}$ ). Moreover, the trans Mo$\mathrm{C} \equiv \mathrm{O}$ groups are markedly non-linear, with $\angle[\mathrm{Mo}(1)-\mathrm{C}(1,4)-\mathrm{O}(1,4)]$ of $172.3(3)^{\circ}$ and $173.5(4)^{\circ}$, respectively, which contrast with the close-to-linear $\angle[\mathrm{Mo}(1)-\mathrm{C}(2,3)-\mathrm{O}(2,3)]$ of $178.2(3)^{\circ}$ and 
179.6(3) ${ }^{\circ}$, respectively. These distortions are common for tetracarbonyl molybdenum complexes and are probably driven mainly by the need to minimise steric repulsion between the trans-coordinated carbonyl groups and the bulky chelating organic ligand.

Since the complex cis-[Mo(CO) 4 (pzpy)] does not contain any hydrogen atoms attached to either oxygen or nitrogen, which could promote the occurrence of strong hydrogen bonds, the close packing of these individual species is essentially driven by the need to effectively fill the space, closely mediated by weak $\mathrm{C}-\mathrm{H} \cdots \mathrm{O}$ and $\pi \cdots \pi$ interactions. The relatively long linear conformation and high degree of flexibility (markedly evident from the thermal displacement ellipsoids depicted in Figure 1) of the ethyl acetate group attached to the 2-(3-pyrazolyl)pyridine residue seem a priori to prevent an effective close-packing of individual complexes. In the crystal structure of $\mathbf{1}$, adjacent cis$\left[\mathrm{Mo}(\mathrm{CO})_{4}(\mathrm{pzpy})\right]$ complexes close pack with their substituent groups facing each other and interconnected via two weak $\mathrm{C}-\mathrm{H} \cdots \mathrm{O}$ hydrogen bonding interactions: While the $-\mathrm{CH}_{2}-\mathrm{C}(\mathrm{O}) \mathrm{O}$ group interacts with the coordinated carbonyl from a neighbouring complex, the $\mathrm{N}(3)$-adjacent $\mathrm{C}-\mathrm{H}$ moiety of the pyrazole ring donates its hydrogen to form a contact with the acetate group from the same neighbouring Mo complex (Table 2), thus leading to a hydrogen bonding motif best described by the $R_{2}^{2}$ (13) graph set (Figure 2a) [50]. This pattern of weak hydrogen bonds is recursive along the [010] crystallographic direction and leads to what Bernstein and co-workers described as a "chain of rings" [50]. Indeed, the shortest repetitive chain motif composed of the same types of hydrogen bonds [in this case, $\mathrm{C}(13)-\mathrm{H}(13 \mathrm{~A}) \cdots \mathrm{O}(2)$ ] is that highlighted in green in Figure 2a, topologically described as $C_{2}^{2}(14)$. According to Bernstein, the complete notation for this "chain of rings" would be $C_{2}^{2}(14)\left[R_{2}^{2}(13)\right]$. This hydrogen bonding pattern promotes the formation of a one-dimensional undulated supramolecular tape of cis-[Mo(CO) $\left.{ }_{4}(\mathrm{pzpy})\right]$ complexes running parallel to the $b$-axis (Figures $2 \mathrm{~b}$ and 2c). The ethyl acetate groups are further responsible for the spatial connections along the [100] direction of the unit cell between adjacent supramolecular tapes, which pack on top of each other as depicted in Figure 3. In fact, one $-\mathrm{CH}_{2}-$ hydrogen atom [C(15)] interacts with the acetate group of a complex belonging to the adjacent supramolecular tape, leading to the $\mathrm{C}(15)-\mathrm{H}(15 \mathrm{~B}) \cdots \mathrm{O}(6)$ interaction (Figure 3a) which is the strongest registered for compound 1 [ $d_{\mathrm{D} \cdots \mathrm{A}}$ of $\left.3.147(1) \AA\right]$, even though not very directional $\left[\angle(\mathrm{DHA})\right.$ of only $132(1)^{\circ}$ ]. These interactions form a helical chain (Figure 3b), best described by the $C_{2}^{2}(10)$ graph set motif.

Table 2. Hydrogen bonding geometry for the weak $\mathrm{C}-\mathrm{H} \cdots \mathrm{O}$ contacts interconnecting adjacent cis-[Mo(CO) $\left.{ }_{4}(\mathrm{pzpy})\right]$ complexes. ${ }^{\text {a }}$

\begin{tabular}{lcc}
\hline \multicolumn{1}{c}{$\mathbf{D}-\mathbf{H} \cdots \mathbf{A}$} & $\boldsymbol{d}_{\mathbf{D} \cdots \mathbf{A}}(\boldsymbol{\AA})$ & $\angle$ (DHA) $\left.\mathbf{(}^{\mathbf{}}\right)$ \\
\hline $\mathrm{C}(5)-\mathrm{H}(5) \cdots \mathrm{O}(3)^{\mathrm{i}}$ & $3.245(1)$ & $130(1)$ \\
$\mathrm{C}(12)-\mathrm{H}(12) \cdots \mathrm{O}(5)^{\mathrm{ii}}$ & $3.263(1)$ & $147(1)$ \\
$\mathrm{C}(13)-\mathrm{H}(13 \mathrm{~A}) \cdots \mathrm{O}(2)^{\mathrm{ii}}$ & $3.393(1)$ & $146(1)$ \\
$\mathrm{C}(15)-\mathrm{H}(15 \mathrm{~B}) \cdots \mathrm{O}(6)^{\mathrm{iii}}$ & $3.147(1)$ & $132(1)$ \\
\hline
\end{tabular}

a Symmetry transformations used to generate equivalent atoms: (i) $-x, 2-y, 1-z$; (ii) $1-x,-1 / 2+y, 1 / 2-z$; (iii) $-x, 1 / 2+y, 1 / 2-z$. 
Figure 2. Schematic representation, viewed along the three crystallographic directions (i.e., (a) [100], (b) [010] and (c) [001]), of the weak $\mathrm{C}-\mathrm{H} \cdots \mathrm{O}$ hydrogen bonding interactions (represented as dashed green lines) between neighbouring cis-[Mo(CO) $)_{4}$ (pzpy)] complexes, which lead to the formation of a supramolecular tape running parallel to the $b$-axis of the unit cell. Hydrogen atoms which are not involved in the aforementioned interactions and symmetry codes of symmetry-generated atoms mentioned above have been omitted for clarity.
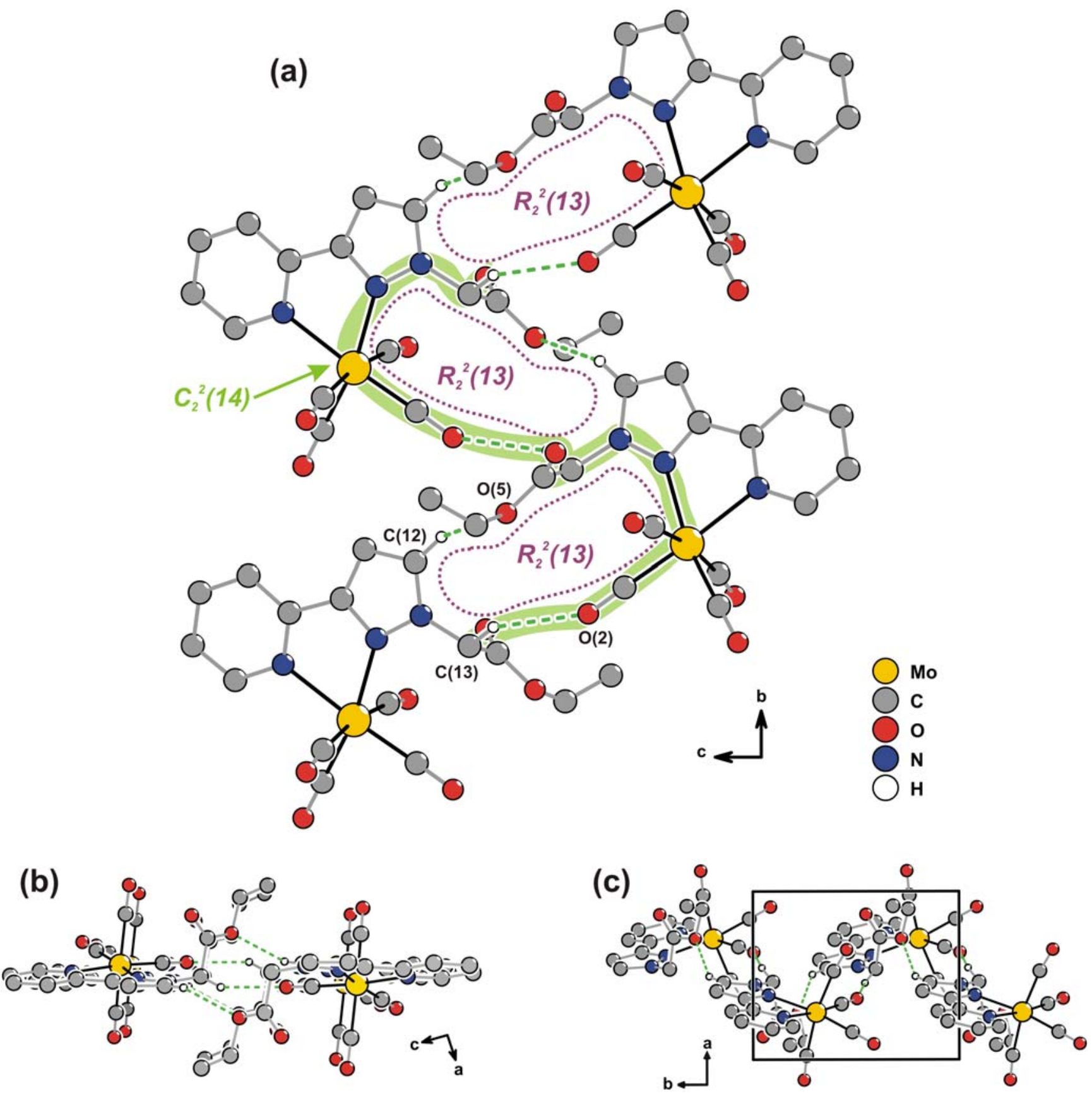
Figure 3. Schematic representation emphasising the $\mathrm{C}_{2}^{2}(10)$ chain of weak $\mathrm{C}-\mathrm{H} \cdots \mathrm{O}$ hydrogen bonding interactions (represented as dashed green lines) running along the [010] direction of the unit cell. These bonds interconnect individual cis-[Mo(CO) $)_{4}($ pzpy)] complexes belonging to different, but adjacent, onedimensional supramolecular tapes (represented with white- and black-filled bonds for each tape). Hydrogen atoms which are not involved in $\mathrm{C}-\mathrm{H} \cdots \mathrm{O}$ hydrogen bonding interactions and all symmetry codes related to symmetrygenerated atoms have been omitted for clarity.

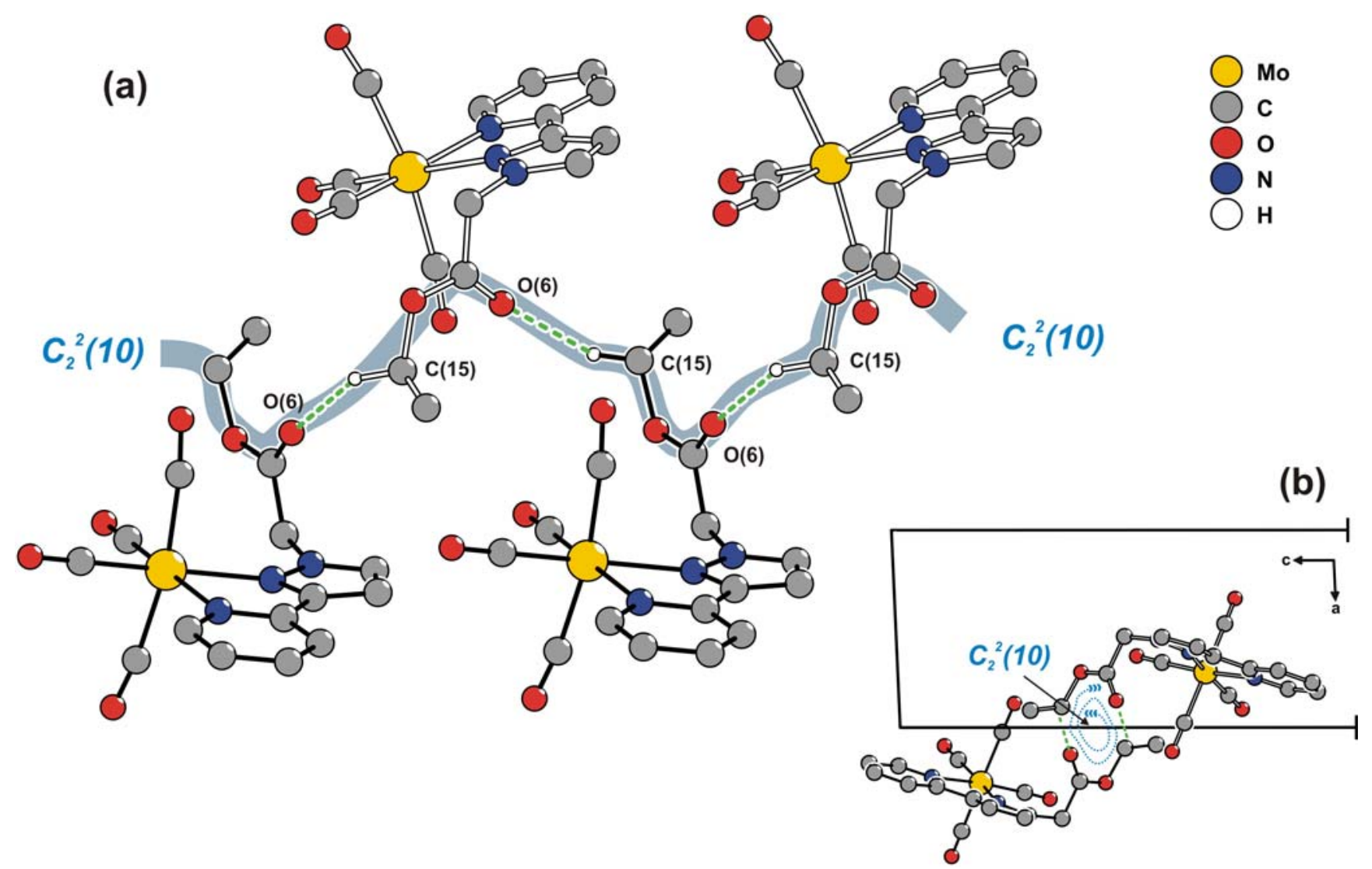

The crystal packing of $\mathbf{1}$ is not mediated only by the $\mathrm{C}-\mathrm{H} \cdots \mathrm{O}$ hydrogen bonding interactions described above. In order for the ethyl acetate groups to be structurally positioned to maximise those weak $\mathrm{C}-\mathrm{H} \cdots \mathrm{O}$ contacts, the 2-(3-pyrazolyl)pyridine residues have to be structurally located on top of each other, slightly offset packed via a series of weak $\pi \cdots \pi$ contacts, as emphasised in Figure 4 . Hence, the crystal structure of $\mathbf{1}$ is ultimately formed when columnar arrangements of hydrogen-bonded supramolecular tapes are packed in a parallel fashion along the [001] direction via $\pi \cdots \pi$ interactions, with an average interplanar distance of about $3.5 \AA$.

\section{Conclusions}

A two-stage reaction is often used for the synthesis of tetracarbonyl complexes of the type cis$\left[\mathrm{M}(\mathrm{CO})_{4}(\mathrm{~L})_{\mathrm{n}}\right]$, with the first step being the synthesis of adducts such as cis-[Mo(CO $\left.)_{4}(\mathrm{pip})_{2}\right]$ and [W(CO) $5(\mathrm{THF})]$. Here we have shown here that molybdenum and tungsten tetracarbonyl complexes bearing the ligand ethyl[3-(2-pyridyl)-1-pyrazolyl]acetate can be prepared rapidly and in one step from 
the $\mathrm{M}(\mathrm{CO})_{6}$ starting materials by using microwave-assisted heating in a closed system. The yields are comparable with those achievable by the traditional preparation routes. In addition to the short reaction times, the microwave-assisted synthesis of these compounds requires relatively small quantities of solvents and it is not necessary to use an inert atmosphere. A slightly longer reaction time was required for the formation of the tungsten complex due to the lower reactivity of $\mathrm{W}(\mathrm{CO})_{6}$. The molybdenum complex, cis-[Mo(CO) $)_{4}$ (pzpy)], crystallizes in the space group $P 2_{1} / \mathrm{c}$ and the structure is composed of a single crystallographically unique complex with the metallic centre being coordinated to four carbonyl groups and a bidentate N,N-chelating pzpy residue, giving a coordination geometry that resembles a highly distorted octahedron, $\left\{\mathrm{MoC}_{4} \mathrm{~N}_{2}\right\}$. The substantial deformation arises from the markedly distinct Mo-C and Mo-N bond distances, a significant angular dispersion for the cis and trans octahedral angles, and the fact that the two $\mathrm{N}$-donor atoms and the two carbonyl groups which make up the equatorial pseudo-plane of the $\left\{\mathrm{MoC}_{4} \mathrm{~N}_{2}\right\}$ octahedron are not all located on the same geometrical plane. The close packing of the individual cis-[Mo(CO) $4(\mathrm{pzpy})]$ species is essentially driven by the need to fill the space effectively, closely mediated by weak $\mathrm{C}-\mathrm{H} \cdots \mathrm{O}$ and $\pi \cdots \pi$ interactions. The hydrogen bonding pattern promotes the formation of a one-dimensional undulated supramolecular tape of cis-[Mo(CO) 4 (pzpy)] complexes running parallel to the $b$-axis.

Figure 4. Perspective view of the unit cell contents showing the $\pi \cdots \pi$ contacts between neighbouring aromatic rings of coordinated ethyl[3-(2-pyridyl)-1pyrazolyl]acetate residues belonging to adjacent hydrogen-bonded supramolecular tapes.

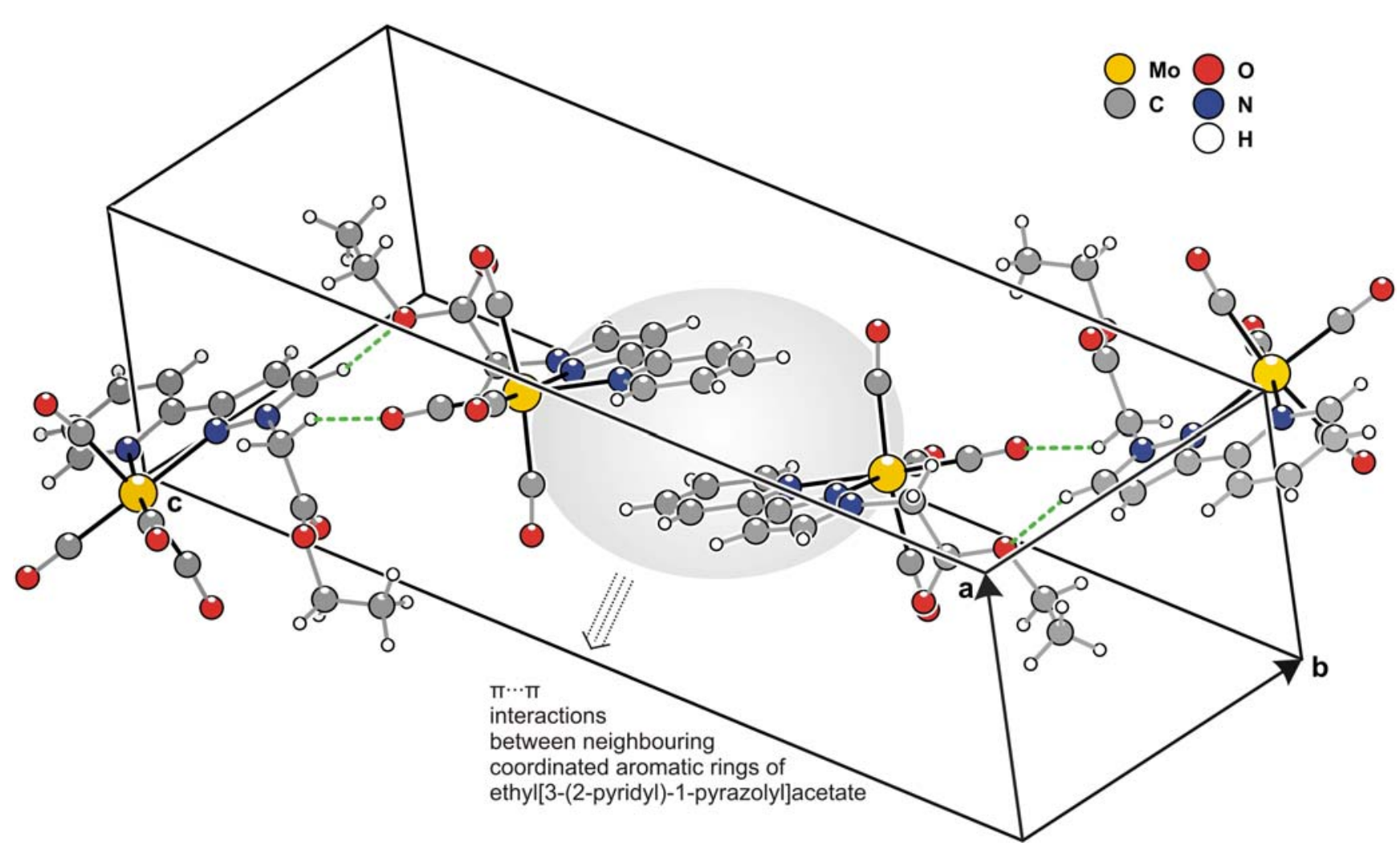




\section{Acknowledgements}

We wish to acknowledge the University of Aveiro, FCT, OE and FEDER (project POCI//QUI/56109/2004) for funding and research grants.

\section{Experimental}

\section{General}

$\mathrm{Mo}(\mathrm{CO})_{6}, \mathrm{~W}(\mathrm{CO})_{6}$ and diethylene glycol dimethyl ether (diglyme) were obtained from Aldrich and Fluka, and used as received. Ethyl[3-(2-pyridyl)-1-pyrazolyl]acetate was prepared using the published procedure [51]. The microwave-assisted syntheses were conducted with a MARS5 microwave oven (CEM Corporation, USA) at $2.45 \mathrm{GHz}$ and a Teflon vessel with a volume of $100 \mathrm{~mL}$. The temperature was monitored with a fibre optic probe inserted inside the Teflon vessel. The vessels were locked onto a carrousel that rotates $360^{\circ}$ clockwise and counter clockwise. The syntheses were carried out using powers of $300 \mathrm{~W}$ (ramp time $30 \mathrm{~min}$ ) and $600 \mathrm{~W}$ (ramp time $45 \mathrm{~min}$ ) for the molybdenum and tungsten complexes, respectively. Elemental analyses were performed on an Exeter Analytical CE 440 Elemental Analyser (University of Cambridge). IR spectra were obtained as $\mathrm{KBr}$ pellets using a Mattson-7000 FTIR spectrophotometer. ${ }^{1} \mathrm{H}$ and ${ }^{13} \mathrm{C}$-NMR spectra were measured in solution using a Bruker Avance 500 Cryo ultrashield spectrometer (University of Cambridge). Chemical shifts are quoted in parts per million from tetramethylsilane.

$\operatorname{cis}-\left[\mathrm{Mo}(\mathrm{CO})_{4}(\right.$ pzpy $\left.)\right](\mathbf{1})$

In a Teflon vessel, $\mathrm{Mo}(\mathrm{CO})_{6}(0.50 \mathrm{~g}, 1.89 \mathrm{mmol})$ was added to a solution of ethyl[3-(2-pyridyl)-1pyrazolyl]acetate $(0.48 \mathrm{~g}, 2.08 \mathrm{mmol})$ in diglyme $(5 \mathrm{~mL})$ and toluene $(10 \mathrm{~mL})$. After heating for $30 \mathrm{~s}$ at $180{ }^{\circ} \mathrm{C}$, the reaction mixture was cooled to room temperature and precipitation was completed with the addition of $n$-hexane. The resultant solid was washed with n-hexane ( $4 \times 10 \mathrm{~mL})$, purified by extraction with diethyl ether $(3 \times 10 \mathrm{~mL})$ and dried in vacuum to yield $\mathbf{1}$ as a dark yellow solid $(0.52 \mathrm{~g}$, 63\%); Anal. Calcd for $\mathrm{C}_{16} \mathrm{H}_{13} \mathrm{~N}_{3} \mathrm{MoO}_{6}$ (439.2): C, 43.75; H, 2.98; N, 9.57. Found: C, 43.86; H, 2.96; N, 9.46\%; Selected IR (KBr, $\left.\mathrm{cm}^{-1}\right): v=3151 \mathrm{~m}, 2991 \mathrm{w}, 2013 \mathrm{~s}, 1887 \mathrm{vs}, 1866 \mathrm{~s}, 1820 \mathrm{vs}, 1750 \mathrm{~s}, 1608 \mathrm{w}$, 1440m, 1418w, 1372m, 1248s, 1213s, 1157m, 1096m, 1074m, 1017m, 866m, 766s, 747m, 648m, 602m, 576m, 553m, 357m; ${ }^{1} \mathrm{H}-\mathrm{NMR}\left(500 \mathrm{MHz}, 25{ }^{\circ} \mathrm{C}, \mathrm{CDCl}_{3}, \mathrm{ppm}\right): \delta=8.99\left(\mathrm{~d},{ }^{3} J_{10,11}=5.5 \mathrm{~Hz}, 1 \mathrm{H}\right.$, $\mathrm{H}^{11}$ ), $7.83\left(\mathrm{dt},{ }^{3} J_{8,9}={ }^{3} J_{9,10}=7.8 \mathrm{~Hz},{ }^{4} J_{9,11}=1.5 \mathrm{~Hz}, 1 \mathrm{H}, \mathrm{H} 9\right), 7.73\left(\mathrm{~d},{ }^{3} J_{8,9}=7.8 \mathrm{~Hz}, 1 \mathrm{H}, \mathrm{H} 8\right), 7.68(\mathrm{~d}$, ${ }^{3} J_{4,5}=2.5 \mathrm{~Hz}, 1 \mathrm{H}, \mathrm{H} 5$ ), 7.25 (ddd, $\left.1 \mathrm{H}, \mathrm{H} 10\right), 6.86$ (d, $\left.{ }^{3} J_{4,5}=2.5 \mathrm{~Hz}, 1 \mathrm{H}, \mathrm{H} 4\right), 5.21$ (s, 2H, NCH$)_{2}, 4.31$ $\left(\mathrm{q},{ }^{3} J_{\mathrm{H}, \mathrm{H}}=7.2 \mathrm{~Hz}, 2 \mathrm{H}, \mathrm{CH}_{2} \mathrm{CH}_{3}\right), 1.32\left(\mathrm{t},{ }^{3} \mathrm{~J}_{\mathrm{H}, \mathrm{H}}=7.2 \mathrm{~Hz}, 3 \mathrm{H}, \mathrm{CH}_{2} \mathrm{CH}_{3}\right) ;{ }^{13} \mathrm{C}-\mathrm{NMR}\left(125.75 \mathrm{MHz}, 25{ }^{\circ} \mathrm{C}\right.$, $\left.\mathrm{CDCl}_{3}, \mathrm{ppm}\right): \delta=221.8,221.7\left(\mathrm{CO}_{\text {eq }}\right), 203.4\left(\mathrm{CO}_{\mathrm{ax}}\right), 166.2\left(\mathrm{CH}_{2} \mathrm{C}(\mathrm{O}) \mathrm{O}\right), 152.9(\mathrm{C} 11), 151.7$ (C7), 151.2 (C3), 137.5 (C9), 134.9 (C5), 123.7 (C10), 121.2 (C8), 104.9 (C4), 62.6 ( $\mathrm{NCH}_{2}$ ), 53.9 $\left(\mathrm{CH}_{2} \mathrm{CH}_{3}\right), 14.0\left(\mathrm{CH}_{2} \mathrm{CH}_{3}\right)$.

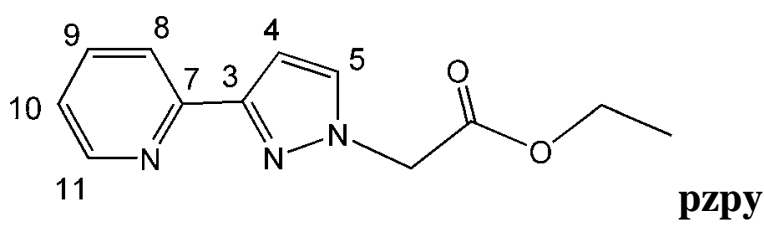


cis- $\left[\mathrm{W}(\mathrm{CO})_{4}(\right.$ pzpy) $](2)$

In a Teflon vessel, $\mathrm{W}(\mathrm{CO})_{6}(0.50 \mathrm{~g}, 1.42 \mathrm{mmol})$ was added to a solution of ethyl[3-(2-pyridyl)-1pyrazolyl]acetate $(0.36 \mathrm{~g}, 1.56 \mathrm{mmol})$ in diglyme $(5 \mathrm{~mL})$ and toluene $(10 \mathrm{~mL})$. After heating for 15 $\min$ at $180{ }^{\circ} \mathrm{C}$, the reaction mixture was cooled to room temperature and precipitation was completed with the addition of n-hexane. The resultant solid was washed with n-hexane $(4 \times 10 \mathrm{~mL})$ and dried in vacuum to yield 2 as a dark yellow solid (0.64 g, 85\%); Anal. Calcd for $\mathrm{C}_{16} \mathrm{H}_{13} \mathrm{~N}_{3} \mathrm{WO}_{6}$ (527.1): C, 36.46; H, 2.49; N, 7.97. Found: C, 36.24; H, 2.49; N, 7.82\%; Selected IR $\left(\mathrm{KBr}, \mathrm{cm}^{-1}\right): v=3149 \mathrm{~m}$, 2996w, 2006s, 1895sh, 1874vs, 1859vs, 1812vs, 1749s, 1611m, 1440m, 1370m, 1336w, 1250s, 1218s, 1139m, 1076m, 1019m, 964w, 766s, 629m, 573m, 564m, 368m; ${ }^{1} \mathrm{H}-\mathrm{NMR}\left(500 \mathrm{MHz}, 25{ }^{\circ} \mathrm{C}, \mathrm{CDCl}_{3}\right.$, ppm): $\delta=9.12\left(\mathrm{~d},{ }^{3} J_{10,11}=5.3 \mathrm{MHz}, 1 \mathrm{H}, \mathrm{H} 11\right), 7.86\left(\mathrm{dt},{ }^{3} J_{8,9}={ }^{3} J_{9,10}=7.8 \mathrm{~Hz},{ }^{4} J_{9,11}=1.5 \mathrm{~Hz}, 1 \mathrm{H}\right.$, H9), 7.77 (d, $\left.{ }^{3} J_{8,9}=7.8 \mathrm{~Hz}, 1 \mathrm{H}, \mathrm{H} 8\right), 7.70$ (d, $\left.{ }^{3} J_{4,5}=2.5 \mathrm{~Hz}, 1 \mathrm{H}, \mathrm{H} 5\right), 7.25$ (ddd, $\left.1 \mathrm{H}, \mathrm{H} 10\right), 6.89$ (d, $\left.{ }^{3} J_{4,5}=2.5 \mathrm{MHz}, 1 \mathrm{H}, \mathrm{H} 4\right), 5.26\left(\mathrm{~s}, 2 \mathrm{H}, \mathrm{NCH}_{2}\right), 4.32\left(\mathrm{q},{ }^{3} J_{\mathrm{H}, \mathrm{H}}=7.2 \mathrm{~Hz}, 2 \mathrm{H}, \mathrm{CH}_{2} \mathrm{CH}_{3}\right), 1.33\left(\mathrm{t},{ }^{3} J_{\mathrm{H}, \mathrm{H}}=\right.$ $\left.7.2 \mathrm{~Hz}, 3 \mathrm{H}, \mathrm{CH}_{2} \mathrm{CH}_{3}\right) ;{ }^{13} \mathrm{C}-\mathrm{NMR}\left(125.75 \mathrm{MHz}, 25{ }^{\circ} \mathrm{C}, \mathrm{CDCl}_{3}, \mathrm{ppm}\right): \delta=214.0,213.0\left(\mathrm{CO}_{\text {eq }}\right), 199.4$ ( $\mathrm{CO}_{\mathrm{ax}}$ ), 166.0 ( $\left.\mathrm{CH}_{2} \mathrm{C}(\mathrm{O}) \mathrm{O}\right), 153.3$ (C7), 153.0 (C11), 152.0 (C3), 137.4 (C9), 134.8 (C5), 124.4 (C10), 121.4 (C8), 105.1 (C4), $62.8\left(\mathrm{NCH}_{2}\right), 54.4\left(\mathrm{CH}_{2} \mathrm{CH}_{3}\right), 14.1\left(\mathrm{CH}_{2} \mathrm{CH}_{3}\right)$.

\section{Single-crystal $X$-ray diffraction}

A suitable single-crystal of cis-[Mo(CO) 4 (pzpy)] (1) was mounted on a glass fibre using FOMBLIN Y perfluoropolyether vacuum oil (LVAC 25/6) purchased from Aldrich [52]. Data were collected at 180 (2) $\mathrm{K}$ on a Nonius Kappa charge-coupled device area-detector diffractometer (Mo $\mathrm{K}_{\alpha}$ graphite-monochromated radiation, $\lambda=0.7107 \AA$ ), equipped with an Oxford Cryosystems cryostream and controlled by the Collect software package [53]. Images were processed using the software packages Denzo and Scalepack [54], and data were corrected for absorption by the empirical method employed in Sortav [55,56]. The structure was solved by the direct methods of SHELXS-97 [57] and refined by full-matrix least squares on $F^{2}$ using SHELXL-97 [58]. All non-hydrogen atoms were directly located from difference Fourier maps and refined with anisotropic displacement parameters.

Hydrogen atoms attached to carbon were located at their idealised positions using appropriate HFIX instructions in SHELXL [58] (43 for the aromatic, 23 and 137 for the $-\mathrm{CH}_{2}$ and terminal $-\mathrm{CH}_{3}$ groups, respectively), and included in subsequent least-squares refinement cycles in riding-motion approximation with isotropic thermal displacement parameters $\left(U_{\text {iso }}\right)$ fixed at 1.2 or 1.5 (for the terminal $-\mathrm{CH}_{3}$ groups) times $U_{\text {eq }}$ of the carbon atom to which they were attached.

Information concerning crystallographic data collection and structure refinement details is summarised in Table 3. The last difference Fourier map synthesis showed the highest peak (0.589 $\mathrm{e} \AA^{-3}$ ) located at $1.86 \AA$ from $\mathrm{C}(14)$, and the deepest hole $\left(-0.739 \mathrm{e} \AA^{-3}\right)$ at $0.28 \AA$ from $\mathrm{O}(5)$.

CCDC-626199 contains the supplementary crystallographic data for this paper. These data can be obtained free of charge via www.ccdc.cam.ac.uk/conts/retrieving.html (or from the CCDC, 12 Union Road, Cambridge CB2 1EZ, UK; fax: +44 1223 336033; e-mail: deposit@ccdc.cam.ac.uk). 
Table 3. Crystal and structure refinement data for cis-[Mo(CO) $\left.)_{4}(\mathrm{pzpy})\right]$ (1).

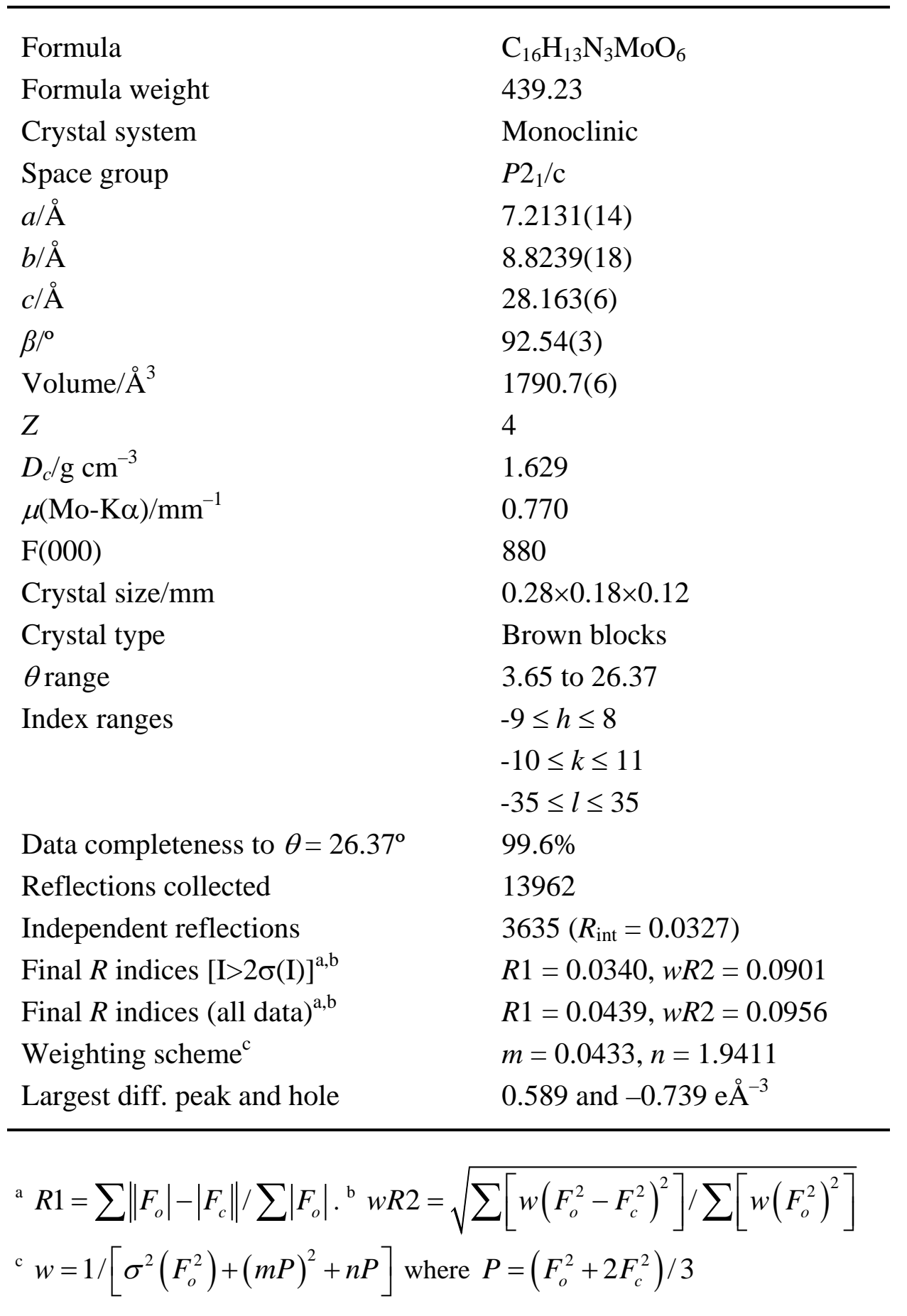

\section{References}

1. Freund, C.; Abrantes, M.; Kühn, F. E. J. Organomet. Chem. 2006, 691, 3718-3729.

2. Petrovski, Ž.; Valente, A. A.; Pillinger, M.; Dias, A. S.; Rodrigues, S. S.; Romão, C. C.; Gonçalves, I. S. J. Mol. Catal. A: Chem. 2006, 249, 166-171.

3. Kimmich, B. F. M.; Fagan, P. J.; Hauptman, E.; Marshall, W. J.; Bullock, R. M. Organometallics 2005, 24, 6220-6229.

4. Kotani, Y.; Kamigaito, M.; Sawamoto, M. Macromolecules 2000, 33, 3543-3549.

5. Lamère, J.-F.; Sasaki, I.; Lacroix, P. G.; Nakatani, K. New J. Chem. 2006, 30, 921-928. 
6. Cariati, E.; Pizzotti, M.; Roberto, D.; Tessore, F.; Ugo, R. Coord. Chem. Rev. 2006, 250, 12101233.

7. Garcia, M. H.; Royer, S.; Robalo, M. P.; Dias, A. R.; Tranchier, J.-P.; Chavignon, R.; Prim, D.; Auffrant, A.; Rose-Munch, F.; Rose, E.; Vaissermann, J.; Persoons, A.; Asselberghs, I. Eur. J. Inorg. Chem. 2003, 3895-3904.

8. Waern, J. B.; Harding, M. M. J. Organomet. Chem. 2004, 689, 4655-4668.

9. Fish, R. H.; Jaouen, G. Organometallics 2003, 22, 2166-2177.

10. Mohler, D. L.; Barnhardt, E. K.; Hurley, A. L. J. Org. Chem. 2002, 67, 4982-4984.

11. Allardyce, C. S.; Dorcier, A.; Scolaro, C.; Dyson, P. J. Appl. Organomet. Chem. 2005, 19, 1-10.

12. Heldt, J.-M.; Fischer-Durand, N.; Salmain, M.; Vessières, A.; Jaouen, G. J. Organomet. Chem. 2004, 689, 4775-4782.

13. van Staveren, D. R.; Weyhermüller, T.; Metzler-Nolte, N. Organometallics 2000, 19, 3730-3735.

14. Johnson, T. R.; Mann, B. E.; Clark, J. E.; Foresti, R.; Green, C. J.; Motterlini, R. Angew. Chem. Int. Ed. 2003, 42, 3722-3729.

15. Brégeault, J.-M. J. Chem. Soc., Dalton Trans. 2003, 3289-3302.

16. Ardon, M.; Hayes, P. D.; Hogarth, G. J. Chem. Educ. 2002, 79, 1249-1251.

17. VanAtta, S. L.; Duclos, B. A.; Green, D. B. Organometallics 2000, 19, 2397-2399.

18. Ardon, M.; Hogarth, G.; Oscroft, D. T. W. J. Organomet. Chem. 2004, 689, 2429-2435.

19. Lidström, P.; Tierney, J.; Wathey, B.; Westman, J. Tetrahedron 2001, 57, 9225-9283.

20. Bruno, S. M.; Pereira, C. C. L.; Balula, M. S.; Nolasco, M.; Valente, A. A.; Hazell, A.; Pillinger, M.; Ribeiro-Claro, P.; Gonçalves, I. S. J. Mol. Catal. A: Chem. 2006, 261, 79-87.

21. Gago, S.; Fernandes, J. A.; Rainho, J. P.; Sá Ferreira, R. A.; Pillinger, M.; Valente, A. A.; Santos, T. M.; Carlos, L. D.; Ribeiro-Claro, P. J. A.; Gonçalves, I. S. Chem. Mater. 2005, 17, 5077-5084.

22. Thiel, W. R.; Priermeier, T.; Fiedler, D. A.; Bond, A. M.; Mattner, M. R. J. Organomet. Chem. 1996, 514, 137-147.

23. Graham, J. R.; Angelici, R. J. Inorg. Chem. 1967, 6, 2082-2085.

24. Allen, F. H. Acta Cryst. B 2002, 58, 380-388.

25. Allen, F. H.; Motherwell, W. D. S. Acta Cryst. B 2002, 58, 407-422.

26. Liang, H. C.; Wu, Y. Y.; Chang, F. C.; Yang, P. Y.; Chen, J. D.; Wang, J. C. J. Organomet. Chem. 2003, 669, 182-188.

27. Morales, D.; Perez, J.; Riera, L.; Riera, V.; Corzo-Suarez, R.; Garcia-Granda, S.; Miguel, D. Organometallics 2002, 21, 1540-1545.

28. Heinze, K. J. Chem. Soc., Dalton Trans. 2002, 540-547.

29. Burgess, J.; Fawcett, J.; Russell, D. R.; Sawbridge, J.; Vu, H. Transition Met. Chem. 2000, 25, 547-551.

30. Shamsudin, M.; Affan, M. A.; Hitam, R.; Yamin, B. M.; Fun, H. K.; Ibrahim, A. R. Z. Krist. New Cryst. Struct. 1999, 214, 499-500.

31. Shamsudin, M.; Affan, M. A.; Hitam, R.; Yamin, B. M.; Boshaala, A. M. A.; Fun, H. K.; Ibrahim, A. R. Z. Krist. New Cryst. Struct. 1999, 214, 215-216.

32. Mentes, A.; Fawcett, J.; Kemmitt, D. W.; Russell, D. R. Acta Cryst. C 1999, 55, 48-50.

33. Herrick, R. S.; Houde, K. L.; Mcdowell, J. S.; Kiczek, L. P.; Bonavia, G. J. Organomet. Chem. 1999, 589, 29-37. 
34. Heard, P. J.; Tocher, D. A. J. Chem. Soc., Dalton Trans. 1998, 2169-2176.

35. Alyea, E. C.; Ferguson, G.; Jain, V. K. Acta Cryst. C 1994, 50, 854-857.

36. Ehlers, J.; Dieck, H. T. Z. Anorg. Allg. Chem. 1988, 560, 80-92.

37. Lu, S. J.; Selbin, J. Inorg. Chim. Acta 1987, 134, 229-232.

38. Bruce, R. S. L.; Cooper, M. K.; Freeman, H. C.; Mcgrath, B. G. Inorg. Chem. 1974, 13, $1032-$ 1037.

39. Veroni, I.; Rontoyianni, A.; Mitsopoulou, C. A. Dalton Trans. 2003, 255-260.

40. Malkov, A. V.; Baxendale, I. R.; Bella, M.; Langer, V.; Fawcett, J.; Russell, D. R.; Mansfield, D. J.; Valko, M.; Kocovsky, P. Organometallics 2001, 20, 673-690.

41. Carr, J. D.; Coles, S. J.; Hursthouse, M. B.; Tucker, J. H. R. J. Organomet. Chem. 2001, 637, 304310.

42. Baxter, P. N. W.; Connor, J. A.; Wallis, J. D.; Povey, D. C.; Powell, A. K. Polyhedron 1992, 11, 1771-1777.

43. Baxter, P. N. W.; Connor, J. A.; Wallis, J. D.; Povey, D. C. J. Organomet. Chem. 1992, 426, $187-$ 194.

44. Wang, X. C.; Cui, Y. X.; Mak, T. C. W.; Wong, H. N. C. J. Chem. Soc., Chem. Commun. 1990, 167-169.

45. Herrmann, W. A.; Thiel, W. R.; Kuchler, J. G.; Behm, J.; Herdtweck, E. Chem. Berichte 1990, 123, 1963-1970.

46. Howie, R. A.; Izquierdo, G.; Mcquillan, G. P. Inorg. Chim. Acta 1983, 72, 165-172.

47. Xie, X. J.; Jin, X. L.; Tang, K. L. Acta Cryst. C 2001, 57, 696-697.

48. Slot, H. J. B.; Murrall, N. W.; Welch, A. J. Acta Cryst. C 1985, 41, 1309-1312.

49. Rossler, K.; Kluge, T.; Schubert, A.; Sun, Y.; Herdtweck, E.; Thiel, W. R. Z. Naturforsch. B 2004, 59, 1253-1263.

50. Bernstein, J.; Davis, R. E.; Shimoni, L.; Chang, N. L. Angew. Chem. Int. Ed. Engl. 1995, 34, 1555-1573.

51. Thiel, W. R.; Angstl, M.; Priermeier, T. Chem. Ber. 1994, 127, 2373-2379.

52. Kottke, T.; Stalke, D. J. Appl. Crystallogr. 1993, 26, 615-619.

53. Hooft, R. Collect: Data collection software, Nonius B.V., 1998.

54. Otwinowski, Z.; Minor, W. in Methods in Enzymology, vol. 276, Eds.: Carter Jr., C. W.; Sweet, R. M., Academic Press, New York, 1997, p. 307.

55. Blessing, R. H. Acta Cryst. A 1995, 51, 33-38.

56. Blessing, R. H. J. Appl. Crystallogr. 1997, 30, 421.

57. Sheldrick, G. M. SHELXS-97, Program for Crystal Structure Solution, University of Göttingen: Göttingen, 1997.

58. Sheldrick, G. M. SHELXL-97, Program for Crystal Structure Refinement, University of Göttingen: Göttingen, 1997.

Sample Availability: Small quantities of compounds $\mathbf{1}$ and $\mathbf{2}$ are available from the authors on request.

(C) 2006 by MDPI (http://www.mdpi.org). Reproduction is permitted for noncommercial purposes. 